\title{
PEG-IFN $\alpha / R B V$ Combination Therapy for Chronic Hepatitis C Patients Increases Serum Ferritin Level while It Improves Sustained Viral Response Rate
}

\author{
Norihisa Yada Masatoshi Kudo Hobyung Chung Sosuke Hayaishi \\ Masahiro Takita Taisuke Ueda Chie Tatsumi Kinuyo Hatanaka Satoshi Kitai \\ Emi Ishikawa Tatsuo Inoue Satoru Hagiwara Kazuomi Ueshima \\ Department of Gastroenterology and Hepatology, Kinki University School of Medicine, Osaka-Sayama, Japan
}

\section{Key Words}

Alanine aminotransferase $\cdot$ Chronic hepatitis $C$.

Combination therapy $\cdot$ Hemolytic anemia $\cdot$ Hepatic iron overload $\cdot$ Pegylated interferon $\cdot$ Ribavirin $\cdot$ Serum ferritin $\cdot$ Sustained viral response

\begin{abstract}
Objectives: We investigated the significance of serum ferritin levels in pegylated interferon (PEG-IFN) and ribavirin (RBV) combination therapy for chronic hepatitis $\mathrm{C}(\mathrm{CHC})$ and examined its correlation with serum alanine aminotransferase (ALT) levels during therapy and response to the therapy. Methods: A total of 175 patients with $\mathrm{CHC}$ received the combination therapy. Correlations between serum ferritin levels and serum ALT levels at 12 and 24 weeks of therapy were examined. Differences in serum ferritin levels during therapy between patients with sustained viral response (SVR) and non-SVR were also examined. Results: Only 24 (13.7\%) and 20 (11.4\%) patients showed elevated serum ALT levels ( $\geq 70$ IU/I) at 12 and 24 weeks of therapy, respectively. There was no correlation between serum ferritin levels and ALT levels. Ninety-five (54.3\%) of 175 patients achieved SVR. Serum ferritin levels increased dramatically in both SVR and non-SVR groups after starting the therapy and were significantly higher in the SVR group throughout the therapy. Conclu-
\end{abstract}

sions: Serum ferritin level increases during PEG-IFN and RBV combination therapy; however, it did not correlate with either serum ALT level or the total dose of RBV. Higher serum ferritin levels during combination therapy appear to be associated with favorable therapeutic response.

Copyright $\odot 2010$ S. Karger AG, Basel

\section{Introduction}

Pegylated interferon (PEG-IFN) and ribavirin (RBV) combination therapy is the current standard treatment for chronic hepatitis C (CHC) infection, demonstrating an improved sustained viral response (SVR) rate even in patients infected with hepatitis $\mathrm{C}$ virus (HCV) genotype 1 and who had a high viral load $[1,2]$. Several host and viral factors contribute to SVR in the combination treatment for Japanese patients infected with HCV genotype 1 with high viral load [3-7]. The host factors include younger age, male gender, mild liver fibrosis, platelet count, LDL cholesterol values and $\gamma$-glutamyl transpeptidase values. The viral factors include amino acid substitutions in the IFN sensitivity-determining region of the $\mathrm{HCV}$ nonstructural 5A (NS5A) protein and in the HCV core region.

\section{KARGER}

Fax +4161306 1234 E-Mail karger@karger.ch www.karger.com (c) 2010 S. Karger AG, Basel

0300-5526/10/0531-0060\$26.00/0

Accessible online at:

www.karger.com/int
Masatoshi Kudo, MD, PhD

Department of Gastroenterology and Hepatology

Kinki University School of Medicine

377-2 Ohno-Higashi, Osaka-Sayama, Osaka 589-8511 (Japan)

Tel. +81 72366 0221, Fax +81 72367 2880, E-Mail m-kudo@ med.kindai.ac.jp 
Hepatic iron overload is frequently observed in patients with HCV infection and has been considered to be associated with disease progression and hepatocarcinogenesis $[8,9]$. However, the association between hepatic iron overload and therapeutic response to IFN therapy for $\mathrm{CHC}$ remains controversial [10-12]. We previously reported that elevation of serum alanine aminotransferase (ALT) levels during PEG-IFN $\alpha$-2a monotherapy for CHC seems to be caused by hepatic iron overload which may be induced by the therapy itself [13].

In this study, we investigated the correlation between serum ferritin levels and serum ALT levels during PEGIFN and RBV combination therapy for $\mathrm{CHC}$, and also investigated whether the elevated serum ferritin level during therapy is associated with a therapeutic response.

\section{Patients and Methods}

\section{Patients}

This retrospective study was conducted at the Kinki University of Medical Science. Eligible subjects were: $\mathrm{CHC}$ patients who had received weekly injections of PEG-IFN $\alpha-2 \mathrm{a}$ or $-2 \mathrm{~b}$ for $24-72$ weeks; who had been followed for more than 24 weeks after treatment, and who had been examined serially for quantitative and qualitative HCV RNA, serum ferritin, serum iron, ALT and complete blood cell counts.

Patients with a high load ( $\geq 100 \mathrm{kIU} / \mathrm{ml}$ ) of HCV genotype 1 were treated for $48-72$ weeks, those with a low load $(<100 \mathrm{kIU} / \mathrm{ml})$ of genotype 1 for 24-48 weeks and those with genotype 2 were treated for 24 weeks. PEG-IFN $\alpha$-2a was administered once a week at a daily dose of 90 or $180 \mu \mathrm{g}$, PEG-IFN $\alpha-2 \mathrm{~b}$ was administered once a week at a daily dose of $1.5 \mu \mathrm{g} / \mathrm{kg}$ body weight. RBV was orally administered daily in 2 divided doses. The doses of RBV were adjusted based on the subject's body weight (600 $\mathrm{mg}$ for $\leq 60$ $\mathrm{kg}, 800 \mathrm{mg}$ for $60-80 \mathrm{~kg}, 1,000 \mathrm{mg}$ for $\geq 80 \mathrm{~kg}$ ). Doses were adjusted during therapy according to standard indications.

Patients with hepatitis B virus infection, HIV infection, autoimmune hepatitis, primary biliary cirrhosis, alcoholic liver disease, non-alcoholic steatohepatitis, hemochromatosis, Wilson's disease and hemoglobinopathy were excluded. Patients were classified as responders if they achieved SVR (defined as undetectable HCV RNA at 24 weeks after the completion of therapy). The remaining patients were categorized as non-SVR. Written informed consent was obtained from all patients before treatment and the protocol was approved by the ethics committee of the Kinki University School of Medicine.

Biochemical and Virological Assay

Laboratory tests including serum ALT levels, serum iron, serum ferritin and complete blood cell counts were assessed in a centralized laboratory using automated methods.

Quantitative HCV testing was performed using the Cobas ${ }^{\circledR}$ Amplicor HCV Monitor Test v.2.0 (Roche Diagnostics, Australia) on the Roche Cobas Amplicor Analyzer (Roche Diagnostics) ac-
Table 1. Demographics and baseline characteristics

\begin{tabular}{lc}
\hline Patients, $\mathrm{n}$ & 175 \\
Age & $60.2 \pm 0.8$ \\
Sex (male/female), n & $85 / 90$ \\
BMI, kg/m ${ }^{2}$ & $22.9 \pm 0.3$ \\
Genotype, $\mathrm{n}$ & $151(86.3 \%)$ \\
$\quad$ & $24(13.7 \%)$ \\
$\quad 2$ & $2,200 \pm 200$ \\
Viral load, kIU/ml & $4.9 \pm 0.1$ \\
WBC, $\times 10^{3} / \mu l$ & $13.8 \pm 0.1$ \\
Hb, g/dl & $16.3 \pm 0.5$ \\
PLT, $\times 10^{4} / \mu l$ & $115.6 \pm 12.5$ \\
Serum ferritin, ng/ml & $71.5 \pm 4.3$ \\
ALT, IU/l & $42(24 \%)$ \\
PEG-IFN, n & $133(76 \%)$ \\
$\quad \alpha-2 \mathrm{a}$ & \\
$\quad \alpha-2 b$ & \\
\multicolumn{2}{c}{ BMI = Body mass index; WBC $=$ white blood cell count; Hb = } \\
hemoglobin; PLT = platelets.
\end{tabular}

cording to the manufacturer's instructions. HCV RNA qualitative determination was performed by real-time PCR on a Cobas TaqMan 48 Analyzer or by Cobas Amplicor HCV Test, v.2.0 (Roche Diagnostics) on the Roche Cobas Amplicor Analyzer with a sensitivity limit of at least $50 \mathrm{IU} / \mathrm{ml}$. Laboratory tests and HCV RNA were analyzed before treatment and at 4, 12 and 24 weeks after initiation of therapy, at the end of the treatment period and $4,12,24$ and 48 weeks following completion of therapy.

\section{Statistical Analysis}

Data were expressed as the means \pm standard errors. Differences between groups were determined by Wilcoxon's signed rank test and confirmed by the non-parametric Mann-Whitney $\mathrm{U}$ test between groups. Correlation between data was tested using the non-parametric Spearman rank correlation analysis. Differences were considered statistically significant at $p<0.05$. Statistical calculations were performed using the commercially available software SPSS v.11.5 (SPSS, Chicago, Ill., USA).

\section{Results}

\section{Demographics and Baseline Features}

Of the 187 patients, 12 discontinued treatment due to adverse events. The remaining 175 patients, consisting of 90 (51.4\%) women and 85 men (48.6\%), who met the requirements were enrolled in the study. HCV genotype 1 was prevalent in $151(86.3 \%)$ patients with the remaining 24 (13.7\%) positive for type 2. PEG-IFN $\alpha$-2b was administered to $133(76 \%)$ of the patients (table 1$)$. 
Table 2. Univariate analysis for SVR

\begin{tabular}{lccc}
\hline & SVR & Non-SVR & p value \\
\hline Patients, $\mathrm{n}$ & 95 & 80 & \\
Age, years & $60.2 \pm 1.2$ & $60.1 \pm 9.0$ & 0.418 \\
Sex (male/female), n & $50 / 45$ & $35 / 45$ & 0.243 \\
BMI, kg/m & $22.6 \pm 4.4$ & $23.2 \pm 0.3$ & 0.173 \\
Genotype & & & $<0.05$ \\
$\quad 1$ & $74(49.0 \%)$ & $77(51.0 \%)$ & \\
$\quad 2$ & $21(87.5 \%)$ & $3(12.5 \%)$ & \\
Viral load, kIU/ml & $1,700 \pm 200$ & $2,700 \pm 400$ & $<0.05$ \\
WBC, $\times 10^{3} / \mu l$ & $5.1 \pm 0.2$ & $4.6 \pm 0.2$ & $<0.05$ \\
Hb, g/dl & $14.0 \pm 0.1$ & $13.6 \pm 0.2$ & $<0.05$ \\
PLT, $\times 10^{4} / \mu \mathrm{l}$ & $17.8 \pm 0.6$ & $14.6 \pm 0.7$ & $<0.05$ \\
Serum ferritin, ng/ml & $135.9 \pm 14.6$ & $174.1 \pm 19.9$ & 0.214 \\
ALT, IU/l & $73.6 \pm 6.5$ & $69.0 \pm 5.3$ & 0.494 \\
PEG-INF & & & 0.321 \\
$\quad \alpha-2 \mathrm{a}$ & $20(47.6 \%)$ & $22(52.4 \%)$ & \\
$\quad \alpha-2 \mathrm{~b}$ & $75(56.4 \%)$ & $58(43.6 \%)$ & \\
\hline
\end{tabular}

$\mathrm{BMI}=$ Body mass index $\mathrm{WBC}=$ white blood cell count; $\mathrm{Hb}=$ hemoglobin; PLT = platelets

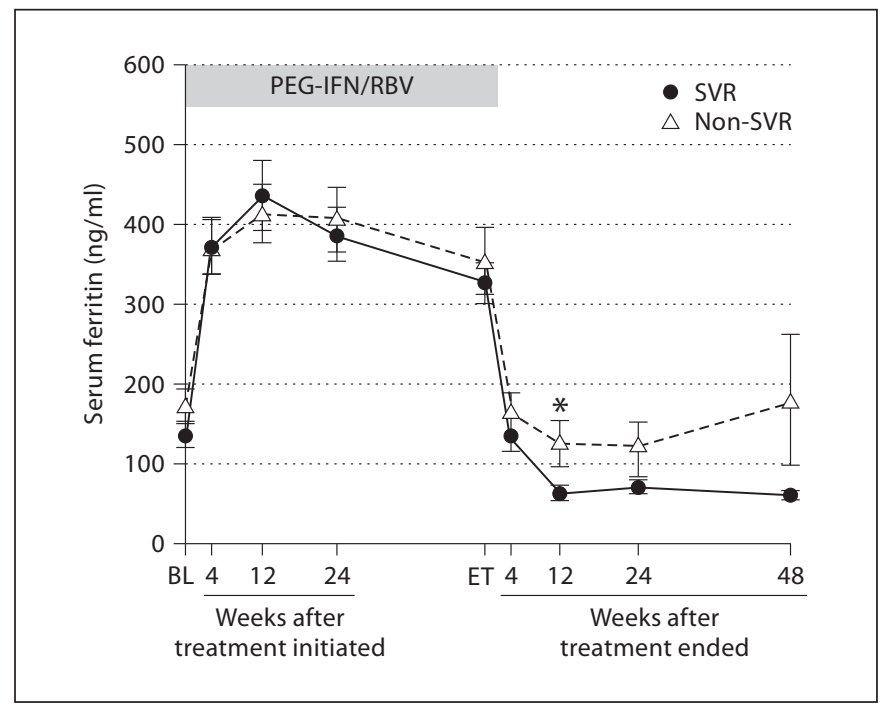

Fig. 1. Serum ferritin levels during and after treatment in patients with or without a SVR. Changes over time of serum ferritin levels in SVR and non-SVR patients after antiviral therapy are displayed. $\mathrm{BL}=$ Baseline; ET $=$ end of treatment. ${ }^{*} \mathrm{p}<0.05$, comparing between groups at each time point.

was no significant relation between serum ALT and ferritin levels at each time point $(\mathrm{p}=0.838, \mathrm{r}=-0.049$ at week $12 ; \mathrm{p}=0.142, \mathrm{r}=0.340$ at week 24$)$.

\section{Dynamics of Serum Ferritin Level during and after \\ Treatment}

Serum ferritin levels increased and peaked between 4 and 12 weeks after commencement of therapy, remained high until the end of the treatment period, and returned to baseline levels after completion of the treatment. If SVR did not occur, serum ferritin levels increased again following completion of therapy (fig. 1). The increasing ratio of serum ferritin' was calculated as the ratio of serum ferritin level to baseline serum ferritin level. The increasing ratio of serum ferritin in patients with a SVR was significantly higher than that in non-SVR individuals during treatment (fig. 2).

\section{Correlation between Dosage of PEG-IFN or RBV and Increasing Ratio of Serum Ferritin}

We analyzed the relationship between administered doses and serum ferritin during the first 4 and 12 weeks of treatment by Pearson's correlation coefficient test. There was no significant correlation between the administered dose of RBV and increasing ratio of serum ferritin $(\mathrm{p}=0.110, \mathrm{r}=0.166$ during the first 4 weeks; $\mathrm{p}=0.071$, 


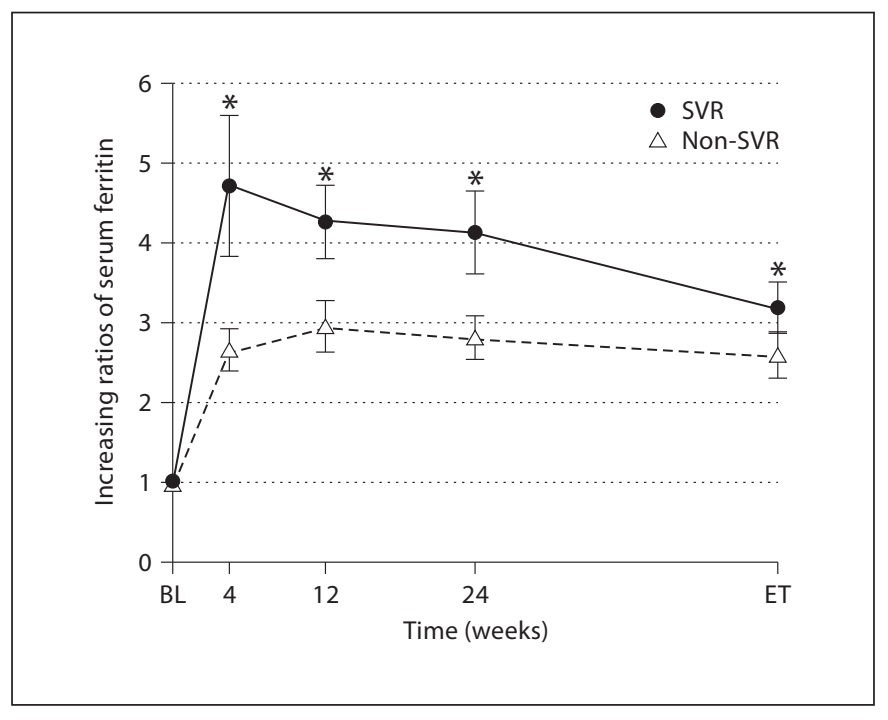

Fig. 2. Increasing ratios of serum ferritin during treatment in patients with or without a SVR. The increasing ratio of serum ferritin' was calculated as the ratio of serum ferritin level to baseline serum ferritin level. $\mathrm{BL}=$ Baseline; $\mathrm{ET}=$ end of treatment. ${ }^{*} \mathrm{p}<$ 0.05 , comparing between groups at each time point.

$\mathrm{r}=0.172$ during the first 12 weeks; fig.3). There was also no correlation between PEG-IFN $\alpha-2 \mathrm{a}$ or $-2 \mathrm{~b}$ and increasing ratio of serum ferritin (PEG-IFN $\alpha-2 \mathrm{a}: \mathrm{p}=0.856, \mathrm{r}=$ 0.037 at week $4 ; \mathrm{p}=0.752, \mathrm{r}=-0.58$ at week 12 ; PEG-IF$\mathrm{N} \alpha-2 \mathrm{~b}: \mathrm{p}=0.692, \mathrm{r}=0.049$ at week $4 ; \mathrm{p}=0.243, \mathrm{r}=0.132$ at week 12).

\section{Discussion}

We previously reported that elevation of serum ALT levels correlated to serum ferritin levels during PEGIFN $\alpha$-2a monotherapy for $\mathrm{CHC}$ seems to be caused by hepatic iron overload, which may be induced by the therapy itself [13]. In this paper, 28 (44.4\%) of 63 patients exhibited elevated ALT levels ( $\geq 70 \mathrm{IU} / \mathrm{l})$. Also, serum ALT levels were elevated ( $\geq 70 \mathrm{IU} / \mathrm{l})$ in $24(13.7 \%)$ of $175 \mathrm{pa}-$ tients at week 12, and in 20 (11.4\%) of 175 patients at week 24. In our present study, during PEG-IFN and RBV combination therapy, there was no elevation of serum ALT level in almost all patients, and there was no significant correlation between serum ferritin and ALT levels.

$\mathrm{RBV}$, a guanosine analogue which has a broad antiviral spectrum, is known as an immunomodulator inhibiting the viral RNA polymerase, balancing Th1 and Th2 cell responses and acting by direct cytoprotection $[14,15]$.
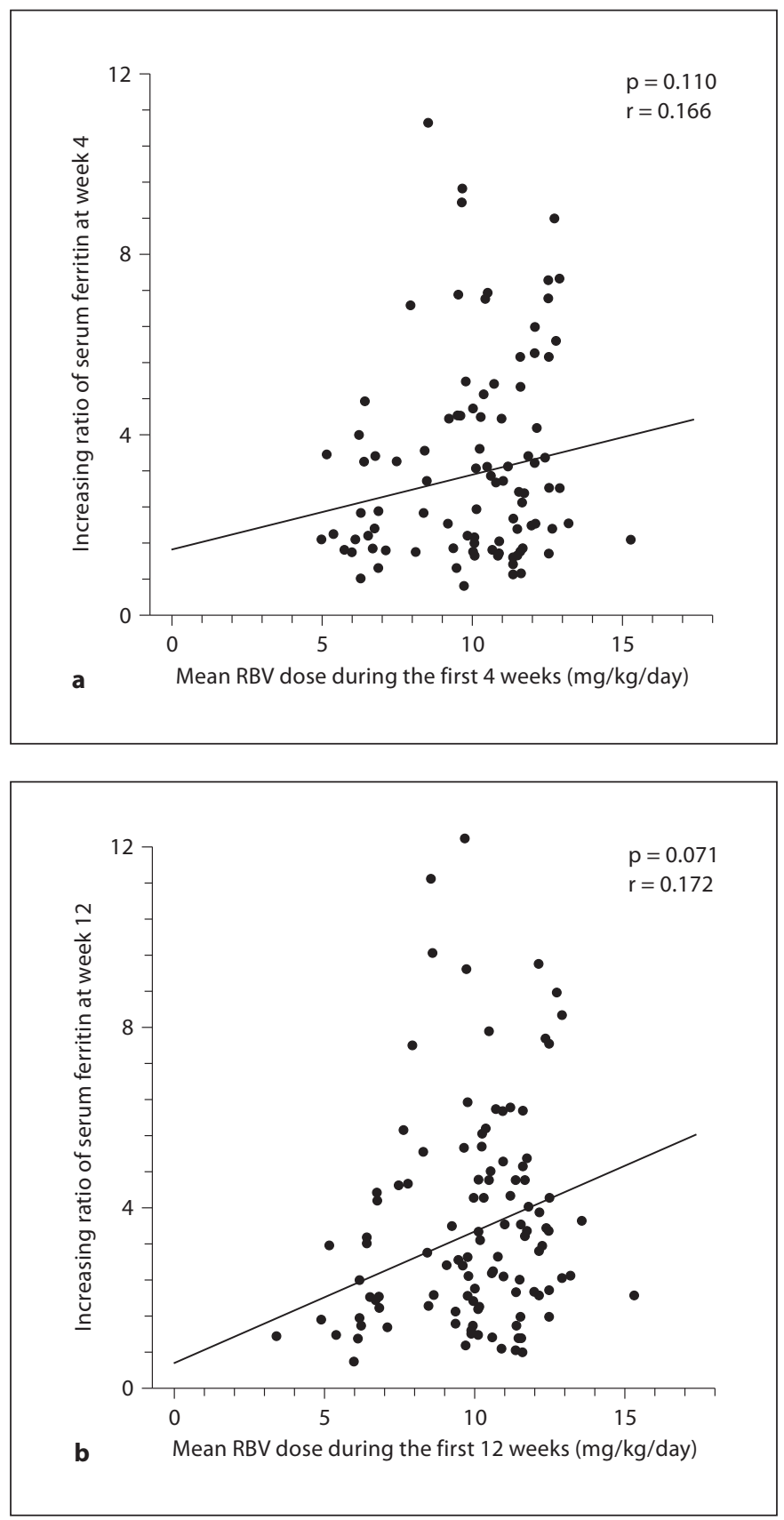

Fig. 3. Correlation between administered doses of RBV and increasing ratio of serum ferritin. The increasing ratio of serum ferritin' was calculated as the ratio of serum ferritin level to baseline serum ferritin level. a Correlation between the mean dose of $\mathrm{RBV}$ and increasing ratio of serum ferritin at week 4 . b Correlation between the mean dose of RBV and increasing ratio of serum ferritin at week 12 . 
Although HCV RNA levels and hepatic fibrosis scores did not change significantly in patients with $\mathrm{CHC}$ who were treated by RBV alone, serum ALT levels and inflammatory features of liver histology were improved $[16,17]$. One possible reason why the correlation between serum ALT and serum ferritin levels was not seen in PEG-IFN and RBV combination therapy, distinct from PEG-IFN $\alpha$ 2a monotherapy, is the efficacy of RBV to improve inflammation of the liver as described above.

In this study, whether SVR was reached or not, serum ferritin levels significantly increased after initiation of therapy, peaked at an early stage (4-12 weeks) after initiation and decreased slowly. In SVR patients, serum ferritin levels after treatment were lower than the initial baseline. In non-SVR patients, serum ferritin levels increased again after completion of therapy with a corresponding increase of HCV-RNA load (data not shown). The increased ratio of serum ferritin (serum ferritin/ baseline ferritin ratio) in SVR subjects was significantly higher than in non-SVR individuals. A similar report has been previously published, and its results correspond with what we are reporting here [18].

In general, it is thought that an adequate dose of RBV in the first stages of treatment correlates to SVR [19]. It is expected that the more RBV is administered, the more strongly hemolysis occurs and serum ferritin levels rise. In this study, there was no significant correlation between dose of RBV and serum ferritin levels. Even if the same dose of RBV was administrated, metabolism and concentration of RBV differ between individuals. Though we did not investigate parameters involving hemolysis or RBV concentration, the correlation between rising levels of ferritin and the rate of SVR may be related to RBV-induced hemolysis and/or RBV concentration. Ferrara et al. [18] considered that the rise of serum ferritin correlated to RBV-induced hemolysis at earlier phases of treatment, but the correlation between serum ferritin levels and hemolysis is lost at later phases of treatment. Therefore, they considered that elevated serum ferritin at a later phase might be caused by a reactive response from activated macrophages to interferon [18]. Their hypothesis that elevation of serum ferritin level during the PEG-IFN and RBV combination therapy might be caused not only by RBV-induced hemolysis but also by IFN is quite reasonable, because elevation of serum ferritin levels is also observed in PEG-IFN $\alpha$-2a monotherapy [13]. Further studies are necessary to confirm these hypotheses.

In conclusion, serum ferritin levels increase during PEG-IFN and RBV combination therapy; however, this did not correlate with either serum ALT levels or the total dose of RBV administered. Higher serum ferritin levels during combination therapy appeared to be associated with favorable therapeutic response.

\section{Disclosure Statement}

The authors declare that they have no financial conflict of interest.

\section{References}

1 Manns MP, McHutchison JG, Gordon SC, Rustgi VK, Shiffman M, Reindollar R, Goodman ZD, Koury K, Ling M, Albrecht JK: Peginterferon alfa- $2 \mathrm{~b}$ plus ribavirin compared with interferon alfa-2b plus ribavirin for initial treatment of chronic hepatitis C: a randomised trial. Lancet 2001;358:958-965.

- 2 Fried MW, Shiffman ML, Reddy KR, Smith C, Marinos G, Goncales FL Jr, Haussinger D, Diago M, Carosi G, Dhumeaux D, Craxi A, Lin A, Hoffman J, Yu J: Peginterferon alfa-2a plus ribavirin for chronic hepatitis $\mathrm{C}$ virus infection. N Engl J Med 2002;347:975-982.
Akuta N, Suzuki F, Kawamura Y, Yatsuji H, Sezaki H, Suzuki Y, Hosaka T, Kobayashi M, Kobayashi M, Arase Y, Ikeda K, Kumada H: Predictive factors of early and sustained responses to peginterferon plus ribavirin combination therapy in Japanese patients infected with hepatitis $C$ virus genotype $1 \mathrm{~b}$ : amino acid substitutions in the core region and lowdensity lipoprotein cholesterol levels. J Hepatol 2007;46:403-410.

-4 Akuta N, Suzuki F, Sezaki H, Suzuki Y, Hosaka T, Someya T, Kobayashi M, Saitoh S, Watahiki S, Sato J, Matsuda M, Kobayashi M, Arase Y, Ikeda K, Kumada H: Association of amino acid substitution pattern in core protein of hepatitis $\mathrm{C}$ virus genotype $1 \mathrm{~b}$ high viral load and non-virological response to interferon-ribavirin combination therapy. Intervirology 2005;48:372-380.
Enomoto N, Sakuma I, Asahina Y, Kurosaki M, Murakami T, Yamamoto C, Izumi N, Marumo F, Sato C: Comparison of fulllength sequences of interferon-sensitive and resistant hepatitis $C$ virus $1 \mathrm{~b}$ : sensitivity to interferon is conferred by amino acid substitutions in the NS5A region. J Clin Invest 1995;96:224-230.

6 Enomoto N, Sakuma I, Asahina Y, Kurosaki M, Murakami T, Yamamoto C, Ogura Y, Izumi N, Marumo F, Sato C: Mutations in the nonstructural protein $5 \mathrm{~A}$ gene and response to interferon in patients with chronic hepatitis C virus 1b infection. N Engl J Med 1996; $334: 77-81$. 
7 Okanoue T, Itoh Y, Hashimoto H, Yasui K, Minami M, Takehara T, Tanaka E, Onji M, Toyota J, Chayama K, Yoshioka K, Izumi N, Akuta N, Kumada H: Predictive values of amino acid sequences of the core and NS5A regions in antiviral therapy for hepatitis C: a Japanese multi-center study. J Gastroenterol 2009;44:952-963.

8 Kew MC: Hepatic iron overload and hepatocellular carcinoma. Cancer Lett 2008. DOI: 10.1016/j.canlet.2008.11.001.

-9 $\overline{\text { Furutani T, Hino K, Okuda }} \mathrm{M}$, Gondo T, Nishina S, Kitase A, Korenaga M, Xiao SY, Weinman SA, Lemon SM, Sakaida I, Okita K: Hepatic iron overload induces hepatocellular carcinoma in transgenic mice expressing the hepatitis $\mathrm{C}$ virus polyprotein. Gastroenterology 2006;130:2087-2098.

10 Akiyoshi F, Sata M, Uchimura Y, Suzuki H, Tanikawa K: Hepatic iron stainings in chronic hepatitis C patients with low HCV RNA levels: a predictive marker for IFN therapy. Am J Gastroenterol 1997;92:1463-1466.
1 Arber N, Moshkowitz M, Konikoff F, Halpern Z, Hallak A, Santo M, Tiomny E, Baratz M, Gilat T: Elevated serum iron predicts poor response to interferon treatment in patients with chronic HCV infection. Dig Dis Sci 1995; 40:2431-2433.

12 Fujita N, Sugimoto R, Urawa N, Araki J, Mifuji R, Yamamoto M, Horiike S, Tanaka $H$, Iwasa M, Kobayashi Y, Adachi Y, Kaito M: Hepatic iron accumulation is associated with disease progression and resistance to interferon/ribavirin combination therapy in chronic hepatitis C. J Gastroenterol Hepatol 2007;22:1886-1893.

13 Nagashima M, Kudo M, Chung H, Ishikawa E, Inoue T, Nakatani T, Dote K: Elevated serum ALT levels during pegylated interferon monotherapy may be caused by hepatic iron overload. Intervirology 2008;51(suppl 1):7685.

14 Lau JY, Tam RC, Liang TJ, Hong Z: Mechanism of action of ribavirin in the combination treatment of chronic HCV infection. Hepatology 2002;35:1002-1009.

$\checkmark 15$ Abonyi ME, Lakatos PL: Ribavirin in the treatment of hepatitis C. Anticancer Res 2005;25:1315-1320.

-16 Bodenheimer HC Jr, Lindsay KL, Davis GL, Lewis JH, Thung SN, Seeff LB: Tolerance and efficacy of oral ribavirin treatment of chronic hepatitis C: a multicenter trial. Hepatology 1997;26:473-477.
17 Dusheiko G, Main J, Thomas H, Reichard O, Lee C, Dhillon A, Rassam S, Fryden A, Reesink H, Bassendine M, Norkrans G, Cuypers T, Lelie N, Telfer P, Watson J, Weegink C, Sillikens $\mathrm{P}$, Weiland $\mathrm{O}$ : Ribavirin treatment for patients with chronic hepatitis C: results of a placebo-controlled study. J Hepatol 1996;25: 591-598.

18 Ferrara F, Ventura P, Vegetti A, Guido M, Abbati G, Corradini E, Fattovich G, Ferrari C, Tagliazucchi M, Carbonieri A, Orlandini A, Fagiuoli S, Boninsegna S, Minola E, Rizzo G, Belussi F, Felder M, Massari M, Pozzato G, Bonetto S, Rovere P, Sardini C, Borghi A, Zeneroli ML, Toniutto P, Rossi E, Pietrangelo A: Serum ferritin as a predictor of treatment outcome in patients with chronic hepatitis C. Am J Gastroenterol 2009; 104: 605-616.

19 McHutchison JG, Manns M, Patel K, Poynard T, Lindsay KL, Trepo C, Dienstag J, Lee WM, Mak C, Garaud JJ, Albrecht JK: Adherence to combination therapy enhances sustained response in genotype-1-infected patients with chronic hepatitis C. Gastroenterology 2002;123:1061-1069. 